\title{
TP63 Gene Product
}

National Cancer Institute

\section{Source}

National Cancer Institute. TP63 Gene Product. NCI Thesaurus. Code C128297.

A protein encoded by the TP63 gene. 